Article

\title{
Automatic Pipeline Route Design with Multi-Criteria Evaluation Based on Least-Cost Path Analysis and Line-Based Cartographic Simplification: A Case Study of the Mus Project in Turkey
}

\author{
Ali İhsan Durmaz ${ }^{1}$, Erdinç Örsan Ünal ${ }^{1}\left(\mathbb{D}\right.$ and Cevdet Coşkun Aydın ${ }^{2, *}$ \\ 1 BOTAŞ Headquarters, Bilkent Plaza A-II Blok, 06800 Bilkent, Ankara, Turkey; \\ aihsan.durmaz@botas.gov.tr (A.İ.D.); erdinc.unal@botas.gov.tr (E.Ö.Ü.) \\ 2 Department of Geomatics, Hacettepe University, 06800 Beytepe, Ankara, Turkey \\ * Correspondence: ceaydin@hacettepe.edu.tr; Tel.: +90-312-297-6990
}

Received: 11 February 2019; Accepted: 31 March 2019; Published: 3 April 2019

\begin{abstract}
The design of a natural gas pipeline route is a very important stage in Natural Gas Transmission Pipeline projects. It is a very complicated process requiring many different criteria for various areas to be evaluated simultaneously. These criteria include geographical, social, economic, and environmental aspects with their obstacles. In the classical approach, the optimum route design is usually determined manually with gathering the spatial references for suitable places and obstructions from the ground. This traditional method is not effective because it does not consider all the factors that affect the route of the pipeline. Today, the powerful tools incorporated in Geographical Information Systems (GIS) can be used to automatically determine the optimum route. An automatic pipeline route finder algorithm can calculate the best convenient route avoiding geographic and topological obstructs and selecting suitable places depending on their weights. In this study, an automatic natural gas pipeline design study was carried out in the east western region of Turkey. At the end of the study, an automatic natural gas pipeline route was determined using GIS and a least cost path algorithm, and an alternative study was conducted using a traditional method. In addition, a cartographic line simplification process with a point removal algorithm was used to eliminate the high vertex points and a simplified route was determined. The results were compared with the results of a finished Mus natural gas project constructed by The Turkish Petroleum Pipeline Corporation (BOTASS) and the negative and positive effects were evaluated. It was concluded that the use of GIS capabilities and the lowest cost path distance algorithm resulted in a $20 \%$ reduction of the cost through the simplification.
\end{abstract}

Keywords: route design; GIS; least cost path analysis; simplification; topographic classification

\section{Introduction}

The construction of natural gas pipelines is an important step for satisfying the energy demand in Turkey and all over the world. Today, due to dynamic economies, rapid population growth and the growing demands of countries for energy, the importance of natural gas pipelines is increasing [1]. Especially in countries with a large land area, such as Turkey, determining economic routes for natural gas pipeline is of great importance. The selection and planning of the optimum pipeline route can provide savings of time and construction and operational costs, together with prolonging operational life and preventing environmental damage and negative effects on local communities [2].

Traditional optimum route planning is undertaken using a combination of 1:25,000 scaled topographic maps and zoning plans. Technical teams carry out the field studies in accordance with 
the preparation of the plans. The necessary data/criteria belonging to different fields of expertise are provided by government departments and include elements, such as highways, rivers, military zones, natural sources, and any obstacles. During this process, a huge amount of data must be examined and analyzed together with many criteria concerning every aspect of the project route [1-3]. Putting all these components together to create a three-dimensional optimum route is a very complex and difficult phase in terms of labor, time, construction, and engineering problems [4].

The aim of this type of study is to ascertain all the criteria and possible risks in order to realize the route that is most suitable and has the least environmental cost in terms of the land use [5]. There are two options to realize this goal. The first option is to determine a number of possible alternative routes with a starting and ending point in a certain region and evaluating the routes using all the necessary criteria and then to select the most suitable route. For the second option, the study is performed on a route that was previously determined by conventional methods and constructed in the field $[3,6,7]$. This new study can be undertaken using today's technologies, which provides the opportunity to use all the criteria to compare the two routes and their alternatives while the route is actively running, and all the predetermined criteria can be observed in the field. In this paper, the authors focused on the second option. To be able to distinguish this study from other work, topographic classifications, such as ridges, flat terrain, steep terrain, and water channels of the study field were specifically taken into consideration and classified using various GIS-based analyses. Thus, this process provided the opportunity to investigate on a continuous surface, rather than a discrete one. In addition, a line-based simplification process with the point removal algorithm was applied and evaluated in relation to the generated route for construction issues.

Today's technologies use skillful software and hardware performance to solve complex engineering problems that have many factors and use large amounts of data. The pipeline route selection with multi criteria is an important and complicated engineering problem [8]. In addition, during the project stage, many problems can be faced. To overcome and facilitate the solution to all these problems, GIS has been used in many Multi-Criteria Decision Making (MCDM) analyses to obtain an accurate and quick result with its powerful and effective tools. MCDM has been used in many scientific works [9-13]. Today the MCDM process is performed with different techniques, such as elimination and choice expressing reality (ELECTRE), analytic hierarchy process (AHP), and the technique for order preference by similarity to ideal solution (TOPSIS). [3,14]. In this study, the AHP technique was used to evaluate the criteria. In general, all criteria can be evaluated with GIS capabilities and intensive geometric and attribute data management are easy to manage with geospatial database management. It is obvious that GIS is sufficiently capable to determine all types of route design [15].

GIS uses many algorithms to analyze and examine various aspects such as the terrain, roads, and power lines to determine optimum routes. An automatic pipeline route finder algorithm should calculate the best convenient route by avoiding geographic and topological obstructs and using suitable places depending on their weights. Automatic pipeline route design is very different from network analysis since a new route can be drawn for each square millimeter of the land [16]. Therefore, we should look for a raster analysis rather than a vector analysis. Moreover, each of the obstructions or the convenient places have different weights on the ground in relation to the pipeline design depending on land usage. For this problem, if we assume that the cost of avoiding an obstruction is higher than passing through a convenient place, we should calculate the least cost path analysis (LCPA) between source and destination point to find the most suitable pipeline route. LCPA provides benefits in calculating linear infrastructures like roads, electricity transmission lines, or new pipeline routes. In this paper, we aimed to automatically calculate the best suitable pipeline route from real world data [5]. LCPA has a number of different GIS applications and according to the research, it has been used in many projects, such as natural gas pipeline planning, and defining power transmission lines and canals [17-21]. 
In this study, determining the pipeline route in a GIS environment is based on the main artery of an existing Turkish natural gas project. The first part of the project is the Muş natural gas pipeline project (MP) from Erzurum to Mus, and the second part is the new pipeline constructed from Muş to Bingöl. This study focuses on MP that was started in 2009 and finished in 2014 with a length of about $156 \mathrm{~km}$. In addition, according to their previous experience, the formal correspondence from BOTAŞ and from government departments were carefully examined, and current geographical data were collected from necessary sources. Then the criteria were determined for routing and evaluated with LCPA to determine the optimum route. After completing the process, the results of the study were compared and evaluated with the MP data.

\section{Study Area, Project Data, and Methodology}

The study area is in the Southeast Anatolia Region of Turkey and located within the boundaries of three provinces: Muss, Ağrı, and Erzurum (Figure 1). The MP project encompassed rural areas with the natural gas pipeline route starting from Ağrı Eleşkirt/Yayladüzü village, and ending in the Muş plain. The starting point of the route has quite high altitude, and the land is rough and not suitable for agriculture. After reaching the Mus plain, the route passes through agricultural land and the terrain is not very rugged. Agriculture spreads around the villages near Ağr1 and Erzurum. In the $3 \mathrm{~km}$ corridor, there are no provincial centers or highly populated areas. During the project stage in the traditional method, due to the high expense of high-pressure pipeline construction, the BOTAS engineers assumed that air distance was the guideline for projects and first tried to explore the natural and artificial obstacles along the potential route. Then the engineers started work in the field, adding a $1 \mathrm{~km}$ buffer zone to the pipeline route, and prepared the first draft of the proposal according to the formal responses from government departments (Table 1). This is an iterative process continuing until the preparation of the final draft pipeline route drawing [22].

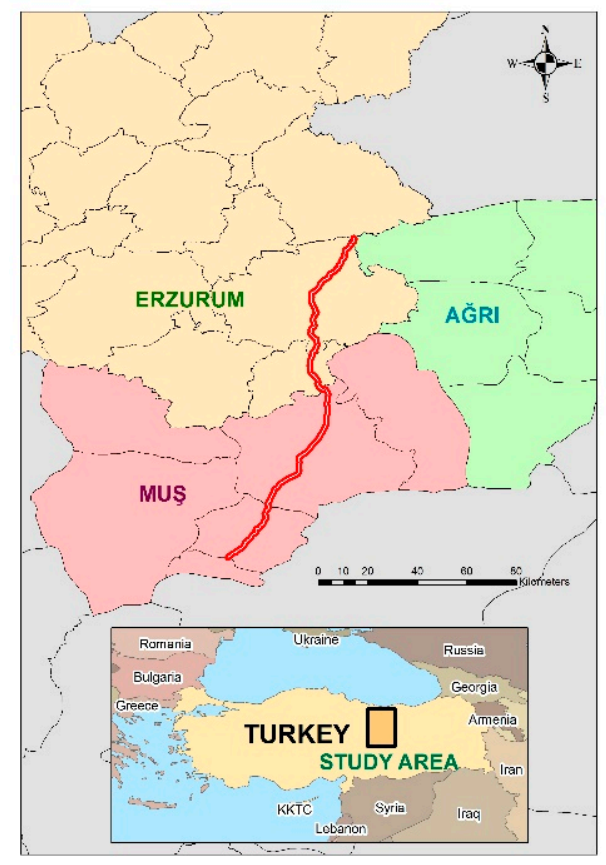

Figure 1. Study area; Muş natural gas pipeline project (MP) covering Erzurum, Ağrı and Muş provinces.

In this study, the most recent draft drawing of the existing MP and the official correspondence from the institutions were obtained as input data. On top of that, an alternative pipeline route to be determined was within $3 \mathrm{~km}$ of the buffer zone of the actual contracted pipeline path. Our aim was to create an automating pipeline path on a GIS platform. In this automation project, to extract the topography, we used Digital Elevation Model (DEM) data provided through the NASA Shuttle Radar 
Topography Mission (SRTM) model, which is open source [23]. The resolutions of SRTM are $30 \mathrm{~m}$ horizontally and $16 \mathrm{~m}$ vertically. All project data were compiled, and raster and vector data sets were converted into spatial data layers, such as appropriate areas, restricted areas, and geological map.

\subsection{Project Data}

The project data has a wide range of different application areas and it is a vital step to collect these data according to the desired standard, accuracy, and scale. In Turkey, different government organizations produce the data at various standards with diverse scales. Therefore, it was necessary to classify and standardize the data from different government organizations (Table 1).

One of the main important steps in natural gas pipeline routing is to define the criteria, weights, and their effects on the route. These criteria and weights indicate the values assigned to the importance ratings [3]. In this study, all criteria including topography, restricted areas, ridges, slopes, rivers, streams, terrain, road and industrial areas were determined with evaluation of the attribute and geometric data, official institution correspondence and expert opinions. All data were prepared as database tables and stored in the GIS database.

Table 1. Project data and standards.

\begin{tabular}{ccccc}
\hline Data & Feature of The Data & Data Type & Scale (1/x) & Source \\
\hline Power Line & Line & Digital file & 25,000 & TEİAŞ Genel Müdürlüğ̈̈ \\
Highway & Raster & Paper & 25,000 & TCK 12.Bölge \\
Dam & Raster & Paper & 25,000 & DSİ 17.Bölge \\
Military Security Zone & Raster & Paper & 25,000 & MUŞ İl Jandarma Komutanlı̆̆1 \\
Power Line & Line & Digital file & 25,000 & Muş TEDAŞ İl Müdürlüğ̈ \\
Highway & Raster & Paper & 25,000 & TCK 11. Bölge \\
Dam Basin & Polygon & Digital file & 25,000 & DSİ Genel Müdürlüğü \\
Highway & Line & Digital file & 25,000 & Karayolları Genel Müdürlüğü \\
Geology & Polygon & Digital file & 25,000 & MTA \\
DEM & Raster & Digital file & $30 \mathrm{~m}$ & NASA \\
\hline
\end{tabular}

\subsection{Classification of Topography}

The topography for defining the best pipeline path should consist of at least four different categories of ridges, streams, flat terrain, and steep terrain. In this study, The DEM data clipped $3 \mathrm{~km}$ within the buffer zone around the real MP.

\subsubsection{Extracting Ridges and Streams}

Ridges are one of the most important natural formations of the natural gas pipeline route. Since these areas have no accumulation of water, especially due to the slope, this situation provides some advantages. The first of which is that these areas are generally far away from agricultural areas, and this is an important factor in deciding on the pipeline path. Another advantage is that the ridges are not affected by erosion, and therefore the pipeline soil is not shifted to another location. The last advantage of these areas is that when compared to other natural formations, the accumulation of water are at a minimum level after the risk of flow and sediment accumulation. In contrast to ridges, streams are one of the worst elements that have an effect on the selection of the pipeline route selection since, like rivers and brooks, they can cross over perpendicularly. There are special precautions, such as precast concrete armor or horizontal drilling; however, in practice, pipeline projects do not follow streams because water erosion risk is at a maximum level at these points. Therefore, pipelines must be kept underground in a very rugged situation. The basic characteristic feature of ridges and streams are related with water accumulation. There is no water accumulation in ridges, but in contrast, streams can be possible drainage channels of water. On the GIS platforms, water accumulation is calculated with the flow direction and flow accumulation functions. 
Flow direction (FD)

The FD analysis shows the steepest drop direction from the selected pixel on the DEM as a pixel value. In this analysis, progressing pixel can be appointed values from 1 to 255 . The steepest drop direction value starts from 1 on the left side pixel and increases geometrically to the top pixel at 128 . If there are multiple currents from the center pixel to its neighbors, this time the steepest drop direction value should be calculated by adding all possible pixel values to the center pixel (Figure 2).

(a)

\begin{tabular}{|c|c|c|}
\hline 32 & 64 & 128 \\
\hline 16 & & 1 \\
\hline 8 & 4 & 2 \\
\hline
\end{tabular}

(b)

\begin{tabular}{|l|l|l|}
\hline 66 & 61 & 63 \\
\hline 61 & 1 & 65 \\
\hline 64 & 73 & 68 \\
\hline
\end{tabular}

Figure 2. Flow direction [24]. (a) Steepest drop direction chart; (b) for example, on the right side, the steepest drop is 61 and its direction values are 16 and 64; therefore, the center pixel has the $16+63=$ 80 value.

\section{Flow Accumulation (FA)}

The FA analysis calculates the accumulated water weight of all pixels using flow directions, and shows the results as a raster output. At the beginning of analysis, one weight of FA is appointed to each cell and this weight moves by the steepest drop direction. After the FA analysis, if a pixel value is zero, these areas should be ridges because ridges do not collect any water. However, if the pixel value is greater this time, we should question the stream channel. In the graphic below, the middle image shows the direction of travel from each cell and the top right image shows the number of cells that flow into each cell (Figure 3).

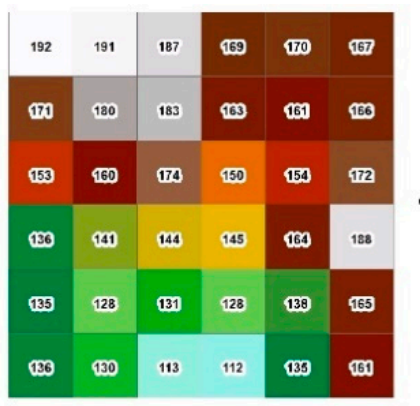

a)Elevation model

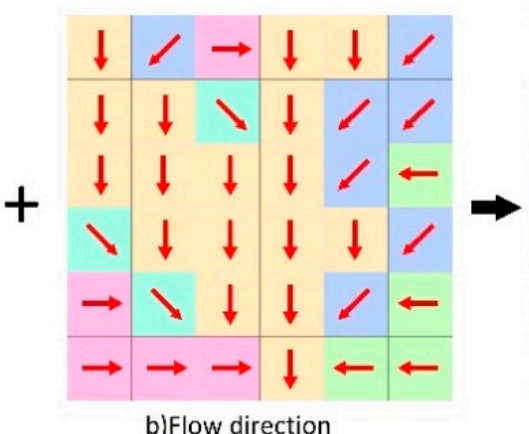

b)Flow direction

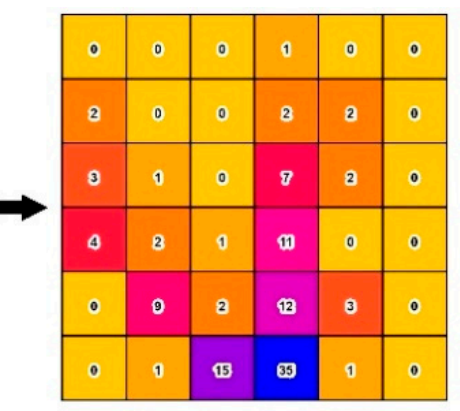

c)Flow accumulation

Figure 3. Flow Accumulation [25].

To find ridges and streams, we need to apply the FA analysis to the DEM. FA analysis requires flow direction raster data. First, we calculate FD, then obtain the FA values (Figure 4). On FA, 0 values mean that there is no water accumulation in these cells; thus, we evaluate these pixels as ridges. In Figure 4, we selected the 20 accumulation value as a threshold. If any pixel becomes greater than this limit grey value, there can be doubt about whether there is a stream channel. On the sample below, the pixels from 0 to the threshold value are non-categorized areas. 


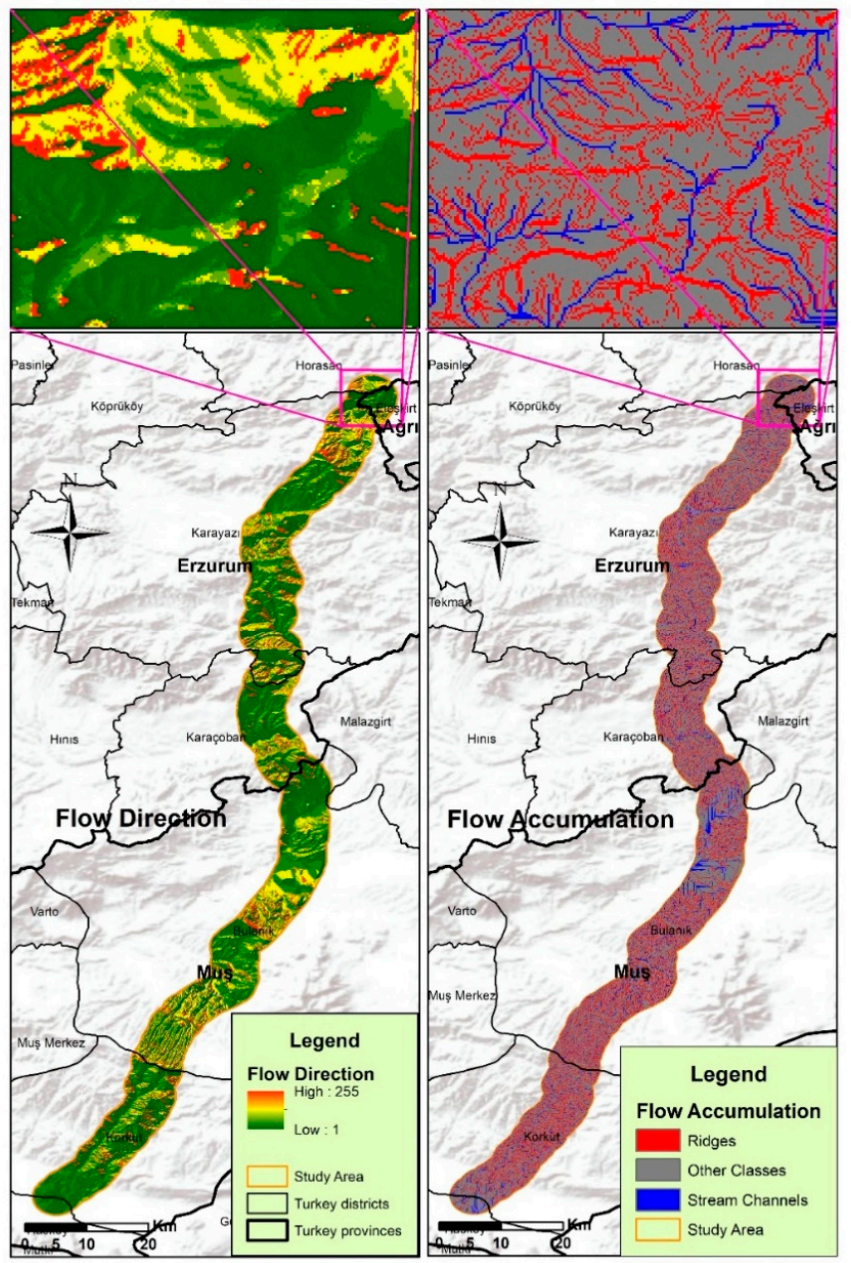

Figure 4. The results of flow direction (FD) and flow accumulation (FA).

\subsubsection{Extracting Flat and Steep Terrain}

The other important parameter for a natural gas pipeline construction/routing is the slope. Working on steep terrain is harder than on flat areas since in the construction stage, heavy equipment cannot work at full capacity on steep terrain areas. According to the previous experience of BOTAS engineers, working on a 30\% slope is possible, but they prefer not to work on higher slopes. The other disadvantage of steep terrain is the risk of erosion. Flat sites are better than steep sites, but flat sites are not the first choice if they contain ridges. On flat areas, heavy construction equipment works well and there is less risk of erosion compared with steep areas [26].

Flat and steep terrain are defined by the slope value. A slope can be calculated by the arc tan function of a change in horizontal direction (delta y) divided by the change in the vertical direction (delta $x)$. The software explains the process of slope calculation (Figure 5)

\begin{tabular}{|c|c|c|c|}
\hline Slope degree $=$ ATAN $\left(\sqrt{\left(\left[\frac{d z}{d x}\right] 2+\left[\frac{d z}{d y}\right] 2\right)}\right) \times \frac{180}{p i}$ & NW & $\mathrm{N}$ & $\mathrm{NE}$ \\
\hline $\begin{array}{l}\text { For horizontal direction change: } \\
\qquad\left[\frac{d z}{d x}\right]=\left((N E+2 E+S E)-\frac{N W+2 W+S W}{8 \times \text { horizontal pixel size }}\right)\end{array}$ & W & & $\mathrm{E}$ \\
\hline $\begin{array}{l}\text { For vertical direction change: } \\
\qquad\left[\frac{d z}{d y}\right]=\frac{(S W+2 S+S E)-(N W+2 N+N E)}{8 \times \text { vertical pixel size }}\end{array}$ & SW & $S$ & SE \\
\hline
\end{tabular}

Figure 5. Slope calculation [26]. 
Flat and steep areas can be sorted after slope analysis on GIS (Figure 6). Applying slope analysis to DEM data gives a result rate of maximum change in elevation from each pixel. For our project, we choose a $20 \%$ slope value as threshold and pixels lower than this value to appoint as a flat site. Higher than this, values are considered as steep sites.

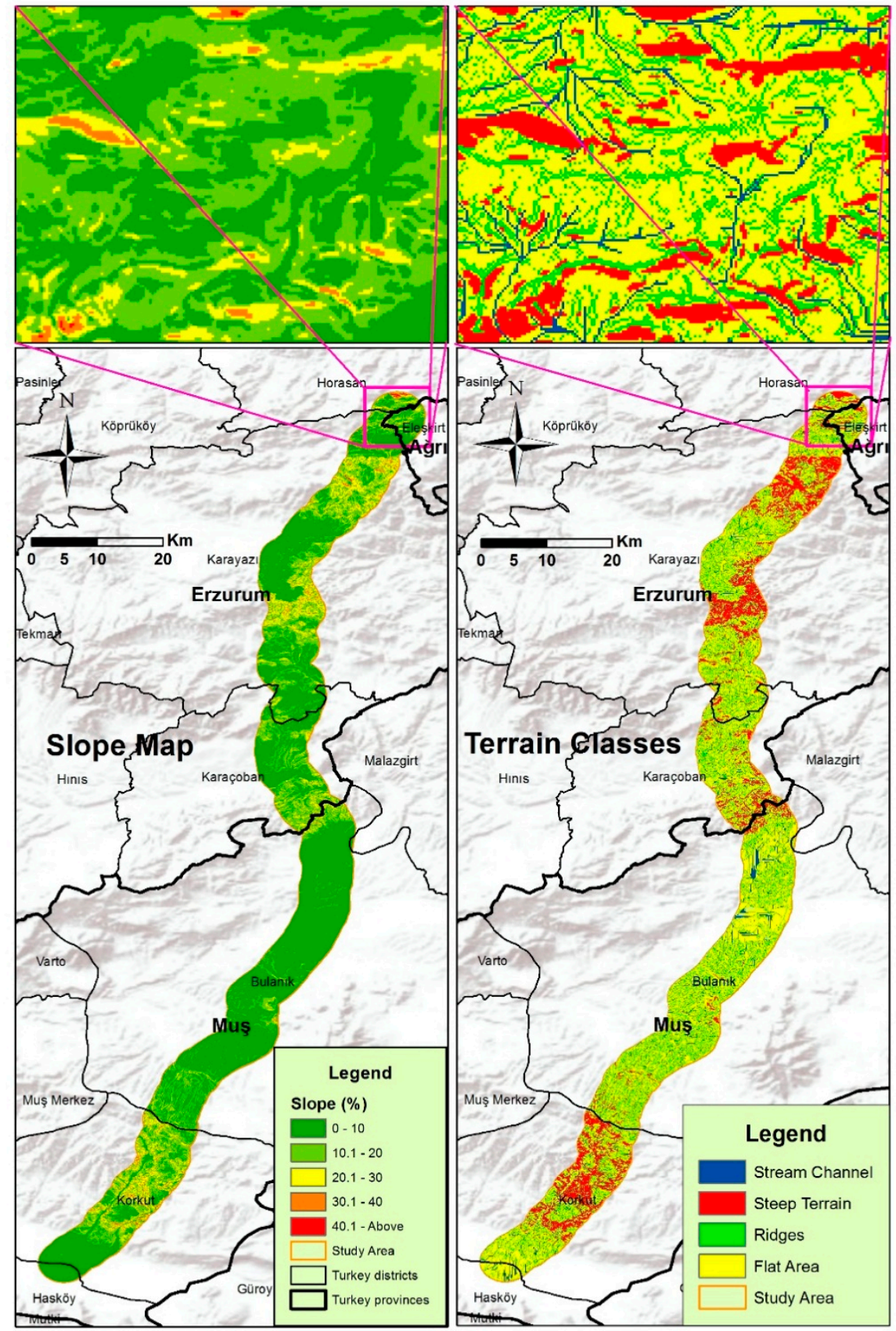

Figure 6. The results of slope map and terrain classification.

2.2.3. Combining the Topographic Data

Combining the two raster data can be undertaken with a raster calculator. There are four steps to create the four categories (Table 2). 
Table 2. Topographic classes.

\begin{tabular}{|c|c|c|}
\hline Step-1 & Steep terrain & $\begin{array}{c}\text { Slope equal or greater than } 20 \% \\
\text { Con("slope" } \geq 20,1,4)\end{array}$ \\
\hline Step-2 & Ridges & $\begin{array}{l}\text { Slope less than } 20 \% \text { and water accumulation equal to } 0 \\
\text { Con }((\text { "flw_accum" }=0) \&(\text { "slope" }<20), 2,4)\end{array}$ \\
\hline Step-3 & Flat terrain & $\begin{array}{l}\text { Slope less than } 20 \% \text { and water accumulation between } 0 \text { to } 100 \\
\text { Con(" } f(\text { flw_accum" }>0) \&(\text { "flw_accum" } \leq 100) \&(\text { "slope" }<20), 3,4)\end{array}$ \\
\hline Step-4 & Stream Channels & $\begin{array}{l}\text { Slope less than } 20 \% \text { water accumulation greater than } 100 \\
\text { Con }((\text { "flw_accum" }>100) \&(\text { "slope" }<20), 0,4)\end{array}$ \\
\hline
\end{tabular}

After these raster algebraic queries, we obtained the four different topographic structures shown in Figure 6.

\subsubsection{Constraints Obstacles and Spatial Data Layers}

In this study, the following three different types of criteria were used: Inappropriate areas, restricted areas, and vertically crossed obstacles. These criteria are constraints that lay on the topography, and can be defined as geometrical shapes. Constraint obstacles were obtained through formal communications from about 30 state agencies in Turkey.

Inappropriate Areas

Inappropriate areas; for example, agricultural irrigation areas, dam reservoirs, and stream channels can be defined as areas through which the natural gas pipeline can pass, but some extra cost may be incurred. In the field application, although some government departments do not recommend passing through their project sites, they do not have strict restrictions if some special precautions are given. These special precautions result in extra cost to the natural gas pipeline project, but this cost may be lower than working around these sites. Moreover, some of these kinds of obstacles can cover all parts of the possible pipeline-working corridor. One of the inappropriate areas is stream channels, in which due to flow risk, natural gas pipeline routing is designed not to pass through stream channels.

In our project corridor, there are some wetlands used for agricultural activities. These sites are not recommended places for routing because of investments like irrigation channels and drilling wells. The formal institutions responsible for agricultural wetlands can allow these fields to be passed over under special precautions provided that there is no harm to existing water channels. In addition to wetlands, the reservoirs of dams are another inappropriate area that may completely cover a working corridor and it is not recommended by government departments to pass through these areas if it is not obligatory. In this study, pipelines had to pass through these areas as the dam reservoir areas covered the entire work area. This results in extra costs for maintenance and repair activities.

The last inappropriate sites are the corridors containing stream channels, which are extracted from topographic analysis. As a result of flow accumulation, higher potential water accumulation sites were presented as a single pixel line. These raster cells were converted into vector lines and the lines were expanded to a 100-m zone using a buffer operation to define inappropriate streamline corridors. LCDA finds the best route depends on each of the weights of the cells. Inappropriate areas are not strictly restricted but are also not recommended to undertake this process in LCDA, these areas were defined by applying extra costs.

\section{Restricted Areas}

Some government institutions do not want pipeline projects to pass through their responsibility areas. For example, municipalities did not allow the pipeline project to pass through their zoning areas because high-pressure pipelines carry a risk of fire and explosion and BOTAŞ also does not want to risk this situation occurring. For security reasons, the other forbidden place for the pipeline is military zones. Areas with a topography slope of more than 30 percent are not considered to be 
suitable. These restricted areas are defined by assigning a null value on the cost surface raster model. LCPA finds the lowest cost path on the model if extra cost is applied to these cells. If these areas are given a null value, the algorithm will remove these areas from the process. In LCDA, these areas were given a null value and left out of the process.

\section{Vertically Crossed Obstacles}

Another type of obstacle is vertically crossed obstacles. These objects are generally in the line-based geometry, which is laid down through all the working corridors. Therefore, it is almost impossible to design a route without taking these hurdles into consideration. In the project site, there will be high voltage power lines, and due to an interference effect, natural gas pipeline routes can be damaged by corrosion. To minimize this, power pipelines should pass through vertically using special precautions. The other obstacle is that it is not recommended for pipelines to pass over these fault lines. Although there are some regulations for these situations, in some cases it is obligatory to pass over these fault lines. Highways are one of the other obstacles that only allow vertical crossing and forbids parallelization between roads and pipelines within $50 \mathrm{~m}$. The last obstacles for this project are agricultural irrigation water channels, which can be under the surface or on the surface. For this obstruction, vertical crosses are defined in LCPA with generating ring buffers. Considering the vertical resolution of the DEM data, in this project 100, 200, and 300-m buffer zones were created around obstacles under this category. The innermost level cost was two times higher than the middle-level buffer zone and the outermost level two times lower than middle level (Figure 7).

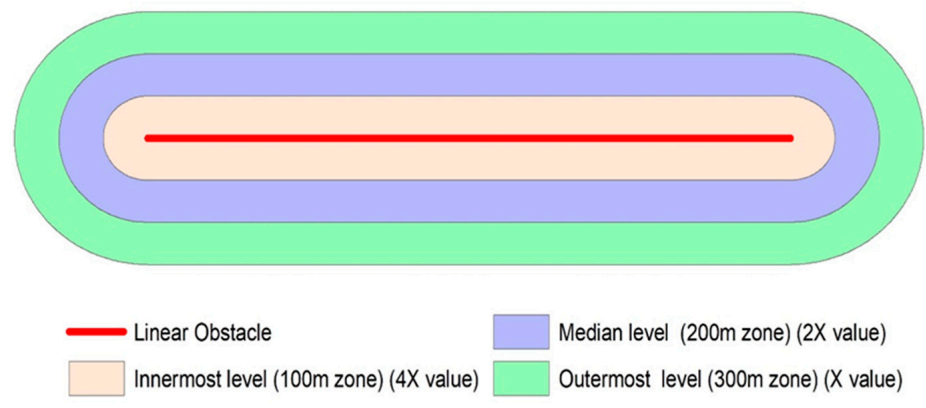

Figure 7. Vertically crossed obstacles.

After using project data and constraint obstacles, spatial data layers were prepared as presented in Figure 8.

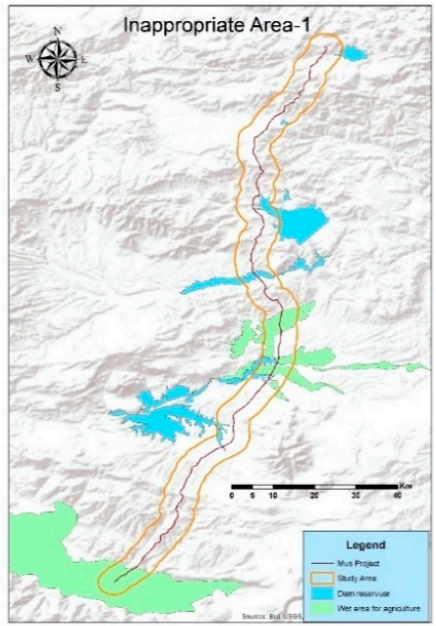

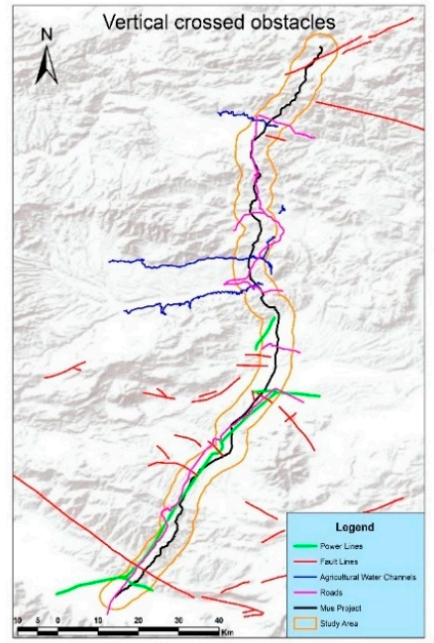

Figure 8. Cont. 

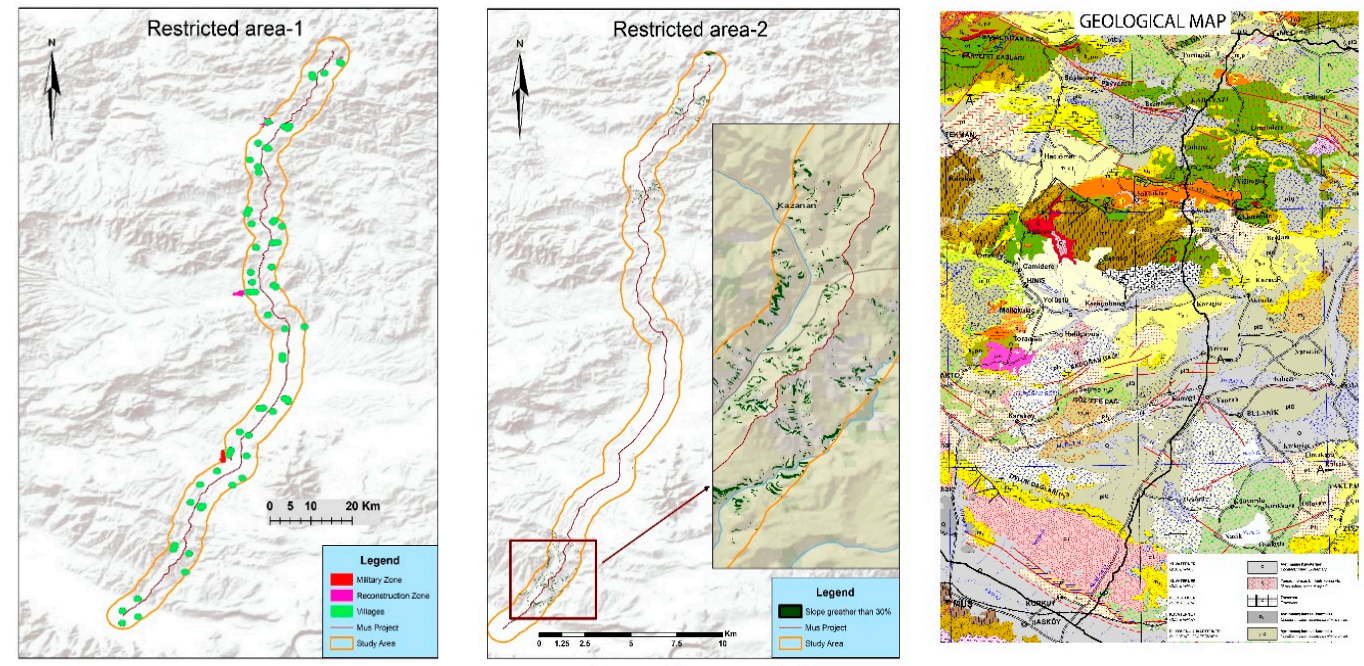

Figure 8. Spatial data layers.

\section{Defining Factors and Weights by AHP}

Route designing/planning work is a process which includes multiple criteria that should be evaluated together to produce the most appropriate solution. The process of harmonization of these criteria is very important. There is no doubt that there are problems in the harmony of all the criteria; therefore, "decision making" is very important in solving these problems. In the application of route design studies, many criteria are examined and evaluated together. Each of these criteria can be significant and effective in determining the route. Some are more preferred, others are more important, and some are indispensable. Therefore, the impact ratios of these factors need to be determined and ranked in order of importance. This stage must be determined systematically in priority order. The statistical analyses are carried out, the necessary factors are determined, and the impact rates of the route are defined using MCDM methods. After determining the factors, the decision-making process is enacted. In this stage, AHP is a very well-known analytical technique, used to solve the complicated decision problems $[27,28]$.

AHP is a technique for analyzing the factors in decision theory. It is an effective tool that may help decision makers to order the priorities to be able to determine the best outcome. The logic of the technique is to reduce complicated decision stages to a series of pairwise comparisons. AHP takes into consideration the necessary criteria and considers the alternative options to achieve the best solution.

Weights related to each criterion are generated according to the decision maker's pairwise comparisons. The values given in terms of the importance of weights are important for their priority. Each factor is awarded the necessary evaluation scores. Therefore, the weight of the score will directly affect the performance. In this study, two different AHP were applied and their weights assumed in equal importance. As a result, AHP generates an overall score for each option by combining the weights and scores of the criteria. In the next stage, it determines the ranking according to this score. More general information about AHP can be found in references [29-31] within the application of cultural heritage, education, and private investment.

In the first place, scoring was undertaken for topography class. The scoring matrix and pairwise weight table are shown in Figure 9. 


\begin{tabular}{|c|c|c|c|c|c|c|c|}
\hline \multicolumn{2}{|r|}{ Category } & Priority & \multicolumn{2}{|r|}{1} & 2 & 3 & 4 \\
\hline 1 & Ridges & $12.0 \%$ & 1 & 1 & 0.50 & 0.33 & 0.50 \\
\hline 2 & Flat Area & $19.1 \%$ & & & & & \\
\hline 3 & Steep Area & $41.8 \%$ & 2 & 2.00 & 1 & 0.50 & 0.50 \\
\hline \multirow[t]{2}{*}{4} & \multirow{2}{*}{ Stream Channels } & \multirow[t]{2}{*}{$27.1 \%$} & & & & & \\
\hline & & & 3 & 3.00 & 2.00 & 1 & 2.00 \\
\hline \multicolumn{3}{|c|}{$\begin{array}{l}\text { Consistency Ratio }(\mathrm{CR})=2.6 \% \\
\text { Princinal Fion value }=4.071\end{array}$} & 4 & 2.00 & 2.00 & 0.50 & 1 \\
\hline
\end{tabular}

Figure 9. Topographic weights and scoring [32].

Then AHP was run for constraint obstacles and the results are shown in Figure 10.

\begin{tabular}{|l|c|c|c|c|c|c|c|}
\hline & 1 & 2 & 3 & 4 & 5 & 6 & 7 \\
\hline 1 & 1 & 3.00 & 1.00 & 2.00 & 1.00 & 3.00 & 2.00 \\
\hline 2 & 0.33 & 1 & 0.33 & 0.50 & 0.25 & 0.50 & 1.00 \\
\hline 3 & 1.00 & 3.00 & 1 & 1.00 & 0.50 & 1.00 & 1.00 \\
\hline 4 & 0.50 & 2.00 & 1.00 & 1 & 0.50 & 1.00 & 1.00 \\
\hline 5 & 1.00 & 4.00 & 2.00 & 2.00 & 1 & 3.00 & 3.00 \\
\hline 6 & 0.33 & 2.00 & 1.00 & 1.00 & 0.33 & 1 & 1.00 \\
\hline 7 & 0.50 & 1.00 & 1.00 & 1.00 & 0.33 & 1.00 & 1 \\
\hline
\end{tabular}

\begin{tabular}{l|ll}
\multicolumn{2}{|l}{ Category } & Priority \\
\hline 1 & Dam Reservoir & $21.7 \%$ \\
2 & Agricultural Irrigation Area (Wet Lands) & $6.40 \%$ \\
3 & Water Channels & $14.0 \%$ \\
4 & Power Lines & $15.5 \%$ \\
5 & Fault Lines & $25.9 \%$ \\
6 & Agricultural Irrigation Channel & $10.4 \%$ \\
7 & Highways & $10.0 \%$
\end{tabular}

(a) Consistency Ratio (CR) $=1.9 \%$

(b) Principal Eigen value $=7.156$

Figure 10. Constraints obstacles weights and scores [32].

\section{Least Cost Distance Analysis}

The determination of a path from one point to another needs to be solved in a network analysis. Defining the shortest path is possible with both raster or vector GIS; however, in practice, raster-based data are used in the routing of linear engineering structures because pipelines are very long and not particularly defined. Raster-based data provides some advantages, such as performing a cost calculation in order to easily use the other raster format data and model different criteria [33,34]. Although there are many distance analysis techniques in GIS, LCPA provides the user with a way to find the cheapest path using raster data. In this method, the eight neighbors of the raster cells are used to move toward the cells with the smallest accumulated or cost value $[24,25,35]$. In the applications, route problems including route determination, selection, planning, and defining is solved by GIS-based LCPA. LCPA has many different applications areas for distance analysis, one of which is to define the natural gas pipeline routing. In this study, LCPA was used to determine the path of the MUS natural gas pipeline.

As previously described, there are different analyses, including FD, FA, and raster calculations with AHP weights. In order to accelerate this process chain, a python script code (Figure 11) was developed in an ArcGIS environment. 


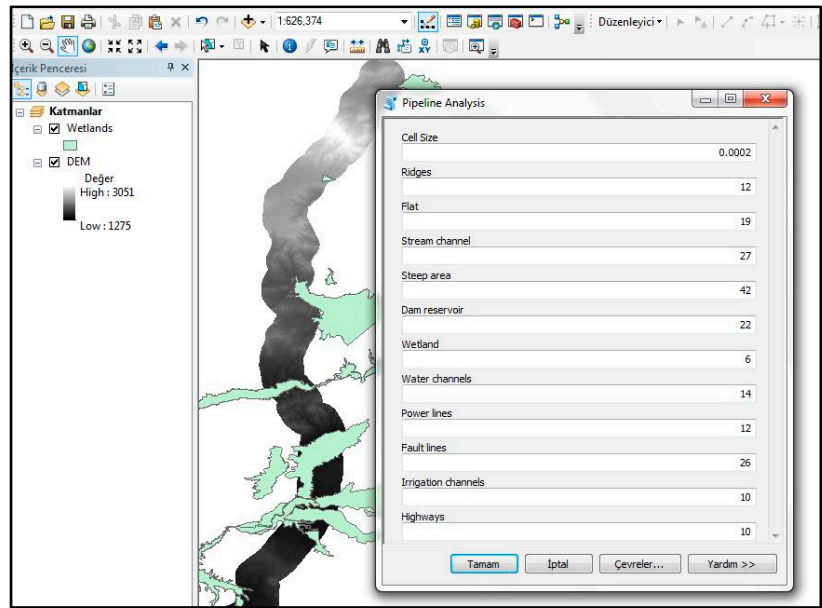

Figure 11. An interface for analysis with script code.

\section{Results and Discussion}

LCPA analysis was run for two different DEM values, $30 \mathrm{~m}$ and $100 \mathrm{~m}$, to obtain the DEM effect on pipeline routing. As a result, a base map, also referred to as a "cost map", was generated in a GIS environment with different scales in a map book display (Figure 12).
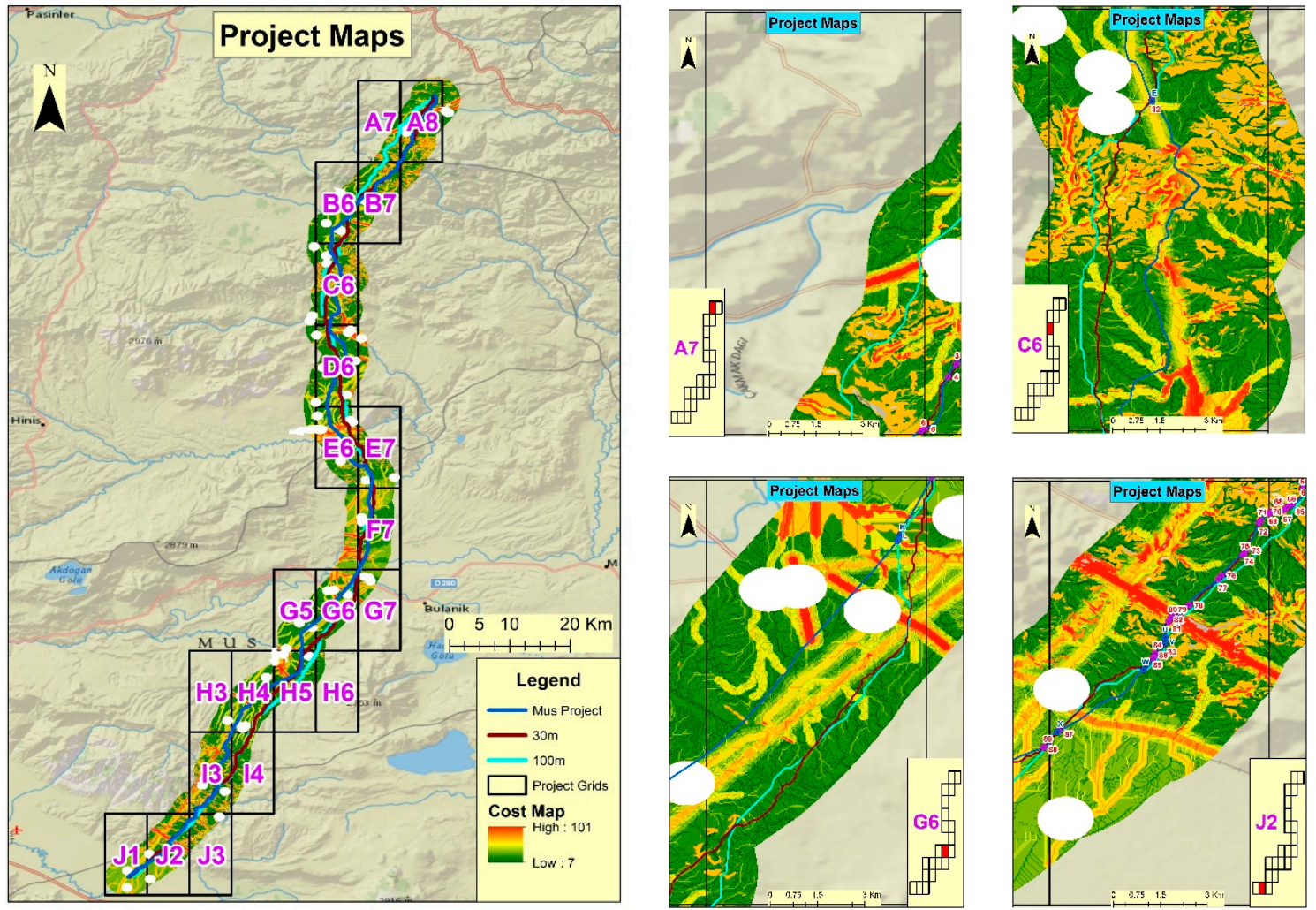

Figure 12. Cost map (base map); the results of $30 \mathrm{~m}$ digital elevation model (DEM), $100 \mathrm{~m}$ DEM and existing Muş project route.

After LCPA, all lengths and cost values were calculated and are displayed in Table 3. From this result, the cost values in $30 \mathrm{~m}$ DEM was decreased by $35 \%$ and the length was reduced by $2.36 \mathrm{~km}$. 
Table 3. Cost and length values after least cost path analysis (LCPA).

\begin{tabular}{cccc}
\hline Cost and Length Values after LCPA & Existing & $\mathbf{3 0 ~} \mathbf{m}$ & $\mathbf{1 0 0} \mathbf{~ m}$ \\
\hline Distance (Length) $(\mathrm{km})$ & 155.83 & 153.47 & 151.12 \\
Cost & 160958 & 104983 & 145425 \\
\hline
\end{tabular}

As a result, a decrease in the cost value was expected and a decrease in the distance value was observed. This has another meaning that the values attributed to the AHP stage gave logical results.

Concerning the topography, the existing pipeline route was compared with the route produced by $30 \mathrm{~m}$ of DEM and $100 \mathrm{~m}$ of DEM (Table 4). According to the results produced by AHP, the weights of the use of ridges and flat areas were close to each other and higher than water channels and steep areas. The $145.89 \mathrm{~km}$ part of the existing project covered ridges and flat land, and the route that was produced from $30 \mathrm{~m}$ DEM covered $146.76 \mathrm{~km}$ of flat land terrain with ridges.

Table 4. The comparison of topography.

\begin{tabular}{cccc}
\hline The Comparison of Topography & Existing & $\mathbf{3 0 ~} \mathbf{~}$ & $\mathbf{1 0 0} \mathbf{~ m}$ \\
\hline Ridges $(\mathrm{km})$ & 54.44 & 77.70 & 36.47 \\
Flat Area $(\mathrm{km})$ & 91.45 & 69.06 & 95.76 \\
Stream channels $(\mathrm{km})$ & 5.09 & 3.46 & 5.54 \\
Steep area $(\geq \% 20)(\mathrm{km})$ & 4.85 & 3.25 & 13.35 \\
Comparison & & & \\
Ridge + flat $(\mathrm{km})$ & 145.89 & 146.76 & 132.23 \\
Ridge + flat $(\%)$ & 93.62 & 95.63 & 87.51 \\
\hline
\end{tabular}

When the results are compared side by side, it can be seen that LCDA clearly offers advantages. For example, $34.93 \%$ of the existing project route passes through ridges, while the result produced by $30 \mathrm{~m}$ DEM passes through more than $50 \%$ ridges. In this stage, it has been concluded that using GIS technology is more capable of determining and extracting the topography compared to traditional methods. Moreover, DEM accuracy is another factor that affects the route design. As seen in Table 5, using $30 \mathrm{~m}$ DEM is more successful than the other values.

Constraint obstacles were evaluated as prohibited regions and others (Table 5). When examining the prohibited regions, it was seen that the results produced by LCDA were drawn more successfully than the existing pipeline route. The entire part of the automatically calculated routes did not enter prohibited zones.

Table 5. Prohibited regions (m).

\begin{tabular}{cccc}
\hline Prohibited Regions (m) & Existing & $\mathbf{3 0 ~} \mathbf{~ m}$ & $\mathbf{1 0 0} \mathbf{~ m}$ \\
\hline Villages (750m buffer zone), Military zone and Restricted Zones & 4507.07 & 0.00 & 0.00 \\
More than 30\% Steep Zones & 325.54 & 0.00 & 0.00 \\
\hline
\end{tabular}

The LCDA was again seen to be more successful as compared to the number of the other constraint obstacles intersections that need to be crossed vertically (Table 6). 
Table 6. The other constraint obstacles.

\begin{tabular}{cccc}
\hline The other Constraining Obstacles & Existing & $\mathbf{3 0 ~} \mathbf{~}$ & $\mathbf{1 0 0} \mathbf{~ m}$ \\
\hline Dam reservoir $(\mathrm{km})$ & 2.75 & 2.21 & 2.46 \\
Irrigational agriculture area $(\mathrm{km})$ & 14.05 & 12.92 & 12.34 \\
Stream channels Within $100 \mathrm{~m}(\mathrm{~km})$ & 12.76 & 8.68 & 9.00 \\
Power lines & 5 times & 3 times & 3 times \\
Fault lines & 5 times & 3 times & 3 times \\
Irrigation channels & 3 times & 2 times & 2 times \\
Highways & 11 times & 7 times & 7 times \\
\hline
\end{tabular}

The lengths of restricted areas were meaningful with LCDA. As seen in Table 6, the lengths obtained were shorter than the existing values. In applications, it is desired/planned that the route has as few vertex points as possible to facilitate construction work. In this study, there was a limitation that the number of vertices on the existing project was less than the suggested route with LCDA. At this point, although the suggested route has many advantages, the number of vertex points is more than the existing route (Table 7).

Table 7. Number of vertex points.

\begin{tabular}{cccc}
\hline Number of Vertex Points & Existing & $\mathbf{3 0 ~} \mathbf{~}$ & $\mathbf{1 0 0 ~} \mathbf{~}$ \\
\hline Vertex Count & 247 & 772 & 265 \\
\hline
\end{tabular}

\section{Simplify Route Planning}

To overcome the problem of the number of vertex points, a line-based cartographic simplification (LBCS) process was applied to the suggested route using $30 \mathrm{~m}$ raster DEM [36,37]. Before applying LBCS, the reason for high vertex points was investigated. For a route design from the start point to the end point with LCDA (Figure 13), the cost will be $107(10+25+15+10+15+20+12)$ and the route will have three vertex points. However, for the optimum route, the cost will be $167(10+25+100+20+12)$ with no vertex points. In the simplifying process, for each vertex, " $h$ " values are calculated, and if this value is greater than $100 \mathrm{~m}$, then that point is removed from the route. The expectation from the simplification process is that it increases the cost and decreases the total length.

\begin{tabular}{|c|c|c|c|c|}
\hline $\begin{array}{c}\text { Start } \\
\text { 10 }\end{array}$ & 35 & 45 & 32 & 40 \\
\hline 29 & 25 & 15 & 10 & 25 \\
\hline 52 & 50 & 100 & 15 & 45 \\
\hline 27 & 65 & 30 & 29 & 28 \\
\hline 35 & 29 & 37 & 39 & $\begin{array}{c}12 \\
\text { End }\end{array}$ \\
\hline
\end{tabular}

Figure 13. The line based cartographic simplification effect on the suggested route.

According to LBCS, the route was re-generated using a point removal algorithm in ArcGIS [32,33]. Figure 14 shows the results after the simplification process, and the result from LBCS, the route criteria, is shown in Table 8.

As expected, a total length of the route is shorter, and the cost increased after the simplification process on the route. After the simplification process, the route was expected to enter the prohibited 
area. However, the route passed about $263.11 \mathrm{~m}$ of a restricted area. Although the process works like this, the results give an advantage of $97 \%$ when compared to the existing pipeline.
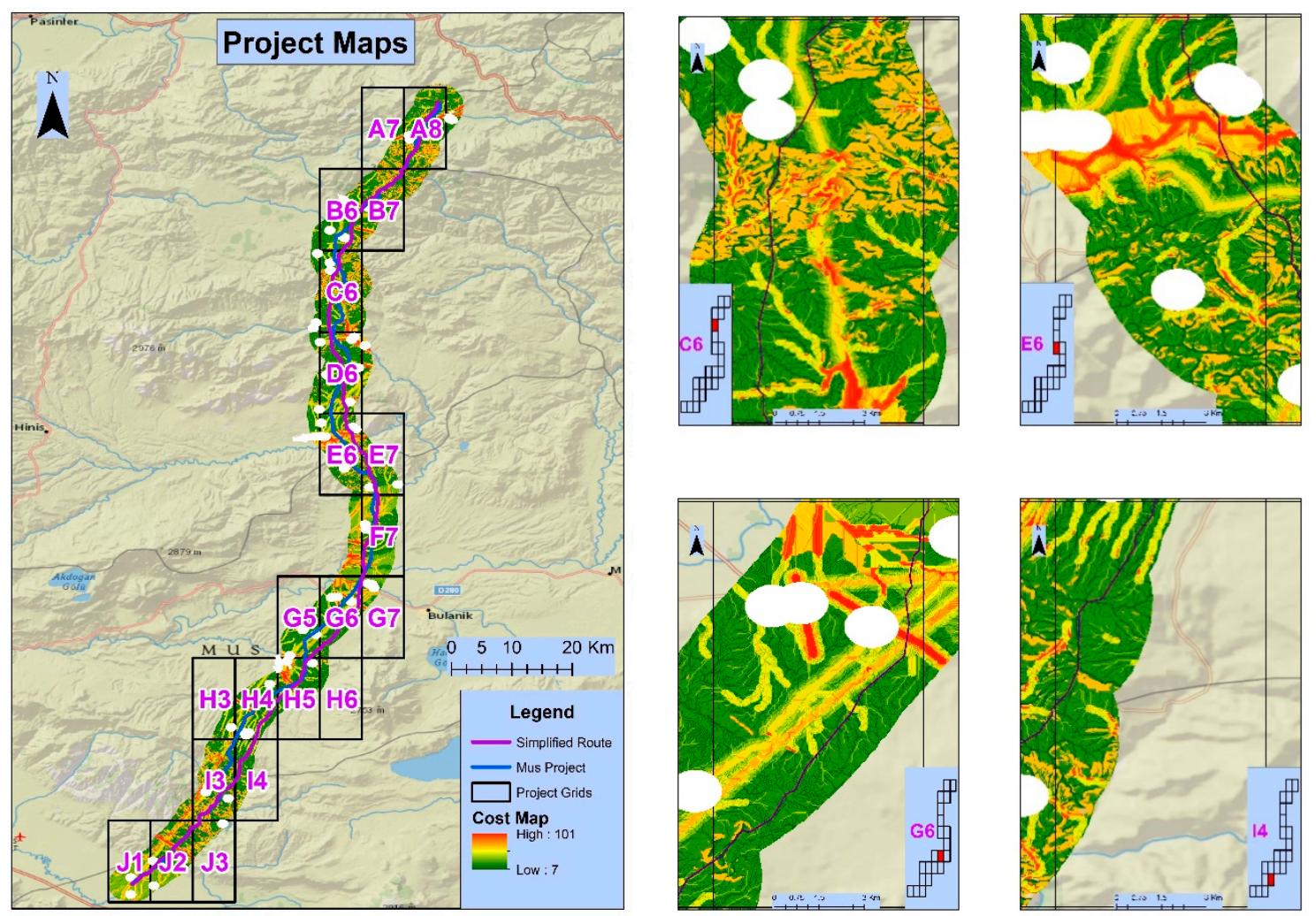

Figure 14. Simplification process on the suggested route.

Table 8. The values obtained from the simplification process and comparison.

\begin{tabular}{cccc}
\hline & Existing & $\mathbf{3 0 ~} \mathbf{~}$ & Simplified \\
\hline Length $(\mathrm{km})$ & 155.83 & 153.47 & 148.99 \\
Cost & 160,958 & 104,983 & 129,053 \\
Ridges $(\mathrm{km})$ & 54.44 & 77.70 & 57.14 \\
Flat areas $(\mathrm{km})$ & 91.45 & 69.06 & 82.39 \\
Stream channels $(\mathrm{km})$ & 5.09 & 3.46 & 4.28 \\
Slope greater than $20 \%$ & 4.85 & 3.25 & 5.18 \\
Ridges + flat area $(\mathrm{km})$ & 145.89 & 146.76 & 139.53 \\
Length in prohibited areas $(\mathrm{m})$ & 4832.61 & 0.00 & 463.11 \\
Power line intersection count & 5 times & 3 times & 3 times \\
Fault line intersection count & 5 times & 3 times & 3 times \\
Highway intersection count & 3 times & 2 times & 2 times \\
Stream channel $(100 m$ buffer zone) & 11 times & 7 times & 7 times \\
Dam reservoir & 12.76 & 8.68 & 9.03 \\
Irrigational agriculture area & 2.75 & 2.21 & 2.50 \\
Number of vertex points & 14.05 & 12.92 & 12.81 \\
\hline
\end{tabular}

With the simplification process, we obtained better results. Before LBCS, we had 772 vertex points on $30 \mathrm{~m}$ resolution route generation. This value was decreased meaningfully to 170 vertex points, showing that LBCS can offer help in evaluating the determination of a natural gas pipeline. 


\section{Conclusions}

Pipeline route design is a complex problem because of the number of inputs. In the classical approach, technical personnel plan the route by passing as easily as possible through the appropriate regions and avoiding obstacles. Appropriate regions and obstacles are identified from 1/25,000 scale maps and official correspondence with government agencies. According to the literature review, LCDA is one of the most appropriate methods to determine a linear infrastructure, such as pipeline routes in the GIS environment. The weights of the appropriate zones and restricted areas can be determined by ranking, and a pairwise comparison using the AHP method.

In this study, we employed the same obstacles used in existing MP. The weights of the topographic criteria and geographic obstacles were evaluated for the AHP method together with engineers who worked on the existing project in 2009. The route generated using LCDA was compared with the existing pipeline and the results were examined for future use in real operations.

According to the results, the cartographic simplified route obtained from $30 \mathrm{~m}$ DEM data provides obvious advantages in every comparison field to the existing route. For example, the reductions were; cost $19.8 \%$, total length $4.4 \%$, prohibited zone uses $90.4 \%$, fault line pass $40.0 \%$, and number of vertex count $31.17 \%$. These results show that LCDA with correct weights can be used in future studies.

Author Contributions: Conceptualization, Ali İhsan Durmaz, Erdinç Örsan Ünal and Cevdet Coşkun Aydın; Methodology, Ali İhsan Durmaz, Erdinç Örsan Ünal and Cevdet Coşkun Aydın; Software, Ali İhsan Durmaz, Erdinç Örsan Ünal and Cevdet Coşkun Aydın; Validation, Ali İhsan Durmaz, Erdinç Örsan Ünal and Cevdet Coşkun Aydın; Formal Analysis, Ali İhsan Durmaz, Erdinç Örsan Ünal and Cevdet Coşkun Aydın; Investigation, Ali İhsan Durmaz, Erdinç Örsan Ünal and Cevdet Coşkun Aydın; Resources, Ali İhsan Durmaz, Erdinç Örsan Ünal and Cevdet Coşkun Aydın; Data Curation, Ali İhsan Durmaz, Erdinç Örsan Ünal and Cevdet Coşkun Aydın; Writing-Original Draft Preparation, Ali İhsan Durmaz, Erdinç Örsan Ünal and Cevdet Coşkun Aydın; Writing-Review \& Editing, Ali İhsan Durmaz, Erdinç Örsan Ünal and Cevdet Coşkun Aydın; Visualization, Ali İhsan Durmaz, Erdinç Örsan Ünal and Cevdet Coşkun Aydın; Supervision, Cevdet Coşkun Aydın; Project Administration, Cevdet Coşkun Aydın.

Funding: This research received no external funding.

Acknowledgments: The Authors thank to The Turkish Petroleum Pipeline Corporation (BOTAŞ) for their contribution for this research.

Conflicts of Interest: The authors declare no conflict of interest.

\section{References}

1. Aydin, C.C.; Karadavut, S. The impact of the increasing use of natural gas on the environment and population in Ankara, Turkey. Fresenius Environ. Bull. 2010, 18, 1559-1566.

2. Huseynli, S. Determination of the Most Suitable Oil Pipeline Route Using GIS Least Cost Path Analysis; Case Study: Keystone XL, NE, USA, 2015; Available online: https:/ / run.unl.pt/bitstream/10362/14553/1/TGEO0138. pdf (accessed on 13 June 2018).

3. Yildirim, V.; Yomralioglu, T.; Nisanci, R.; Çolak, H.E.; Bediroğlu, Ş.; Saralioglu, E. A spatial multicriteria decision-making method for natural gas transmission pipeline routing. Struct. Infrastruct. Eng. 2017, 13, 567-580. [CrossRef]

4. Abudu, D.; Williams, M. GIS-based Optimal Route Selection for Oil and Gas Pipelines in Uganda. ACSIJ Adv. Comput. Sci. Int. J. 2015, 4, 93-104.

5. GIS LOUNGE. Available online: https://www.gislounge.com/overview-least-cost-path-analysis/ (accessed on 18 July 2018).

6. Dedemen, Y.A. Multi-Criteria Decision Analysis Approach to GIS Based Route Selection for Overhead Power Transmission Lines. Master's Thesis, Middle East Technical University, Ankara, Turkey, 2013.

7. Gamarra, A. GIS Suitability Modeling to Support a Pipeline Route Selection, ESRI User Conference in San Diego, CA, 2015. Available online: http:/ / proceedings.esri.com/library/userconf/proc15/papers/1272_ 673.pdf/ (accessed on 19 July 2018).

8. Alanbari, M.E.; Al-Ansari, N.; Jasim, H.K. GIS and multicriteria decision analysis for landfill site selection in Al-Hashimyah Qadaa. Nat. Sci. 2014, 6, 282-304. [CrossRef] 
9. Kabir, G.; Sadiq, R.; Tesfamariam, S. A review of multi-criteria decision-making methods for infrastructure management. Struct. Infrastruct. Eng. 2013, 10, 1176-1210. [CrossRef]

10. Khosravanian, R.; Wood, D. Selection of high-rate gas well completion designs applying multicriteria decision making and hierarchy methods. J. Nat. Gas Sci. Eng. 2016, 34, 1004-1016. [CrossRef]

11. Osorio-Tejada, J.L.; Llera-Sastresa, E.; Scarpellini, S. A multi-criteria sustainability assessment for biodiesel and liquefied natural gas as alternative fuels in transport systems. J. Nat. Gas Sci. Eng. 2017, 42, 169-186. [CrossRef]

12. Abudeif, A.M.; Abdel Moneim, A.A.; Farrag, A.F. Multicriteria decision analysis based on analytic hierarchy process in GIS environment for siting nuclear power plant in Egypt. Ann. Nuclear Energy 2015, 75, 682-692. [CrossRef]

13. Terh, S.H.; Cao, K. GIS-MCDA based cycling paths planning: A case study in Singapore. Appl. Geogr. 2018, 94, 107-118. [CrossRef]

14. Seyedmohammadia, J.; Sarmadian, F.; Jafarzadeha, A.A.; Ghorbanic, M.A.; Shahbazia, F. Application of SAW, TOPSIS and fuzzy TOPSIS models in cultivation priority planning for maize, rapeseed and soybean crops. Geoderma 2018, 310, 178-190. [CrossRef]

15. Joshua, J.K.; Anyanwu, N.C.; Ahmed, A.J. Land suitability analysis for agricultural planning using GIS and multi criteria decision analysis approach in Greater Karu Urban Area, Nasarawa State, Nigeria. Int. J. Appl. Res. Stud. 2013, 2, 1-16.

16. ArcMap. 2018. Available online: http://desktop.arcgis.com/en/arcmap/latest/extensions/networkanalyst/route.htm/ (accessed on 10 July 2018).

17. Atkinson, D.M.; Deadman, P.; Dudycha, D.; Traynor, S. Multi-criteria evaluation and least cost path analysis for an arctic all-weather road. Appl. Geogr. 2005, 25, 287-307. [CrossRef]

18. Gonçalves, A.B. An extension of GIS-based least-cost path modelling to the location of wide paths. Int. J. Geogr. Inf. Sci. 2010, 24, 983-996. [CrossRef]

19. Bagli, S.; Geneletti, D.; Orsi, F. Routeing of power lines through least-cost path analysis and multicriteria evaluation to minimise environmental impacts. Environ. Impact Assess. Rev. 2011, 31, 234-239. [CrossRef]

20. Kang, J.Y.; Lee, B.S. Optimisation of pipeline route in the presence of obstacles based on a least cost path algorithm and laplacian smoothing. Int. J. Naval Archit. Ocean Eng. 2017, 9, 492-498. [CrossRef]

21. Verbrugghe, G.; De Clercq, W.; Eetvelde, V.V. Routes across the Civitas Menapiorum: Using least cost paths and GIS to locate the Roman roads of Sandy Flanders. J. Hist. Geogr. 2017, 57, 76-88. [CrossRef]

22. BOTAŞ. The Turkish Petroleum Pipeline Corporation. 2018. Available online: http://www.botas.gov.tr/ (accessed on 1 August 2018).

23. USGS. The U.S. Geological Survey. 2018. Available online: https:/ / earthexplorer.usgs.gov/ (accessed on 5 August 2018).

24. ArcGIS Pro. 2018. Available online: http://pro.arcgis.com/en/pro-app/tool-reference/spatial-analyst/ how-flow-direction-works.htm/ (accessed on 5 August 2018).

25. ArcGIS Pro. 2018. Available online: http://pro.arcgis.com/en/pro-app/tool-reference/spatial-analyst/ how-flow-accumulation-works.htm/ (accessed on 5 August 2018).

26. ArcMap. 2018. Available online: http://desktop.arcgis.com/en/arcmap/10.3/tools/spatial-analysttoolbox/how-slope-works.htm/ (accessed on 5 August 2018).

27. Bhushan, N.; Rai, K. Strategic Decision Making-Applying the Analytic Hierarchy Process, 1st ed.; Springer: London, UK, 2004; pp. 11-21.

28. Roig-Tierno, N.; Baviera-Puig, A.; Buitrago-Vera, J.; Mas-Verdu, F. The retail site location decision process using GIS and the analytical hierarchy process. Appl. Geogr. 2013, 40, 191-198. [CrossRef]

29. Di Angelo, L.; Di Stefano, P.; Fratocchi, L.; Marzola, A. An AHP-based method for choosing the best 3D scanner for cultural heritage applications. J. Cult. Herit. 2018, 34, 109-115. [CrossRef]

30. Gottfried, O.; De Clercq, D.; Blair, E.; Weng, X.; Wang, C. SWOT-AHP-TOWS analysis of private investment behavior in the Chinese biogas sector. J. Clean. Prod. 2018, 184, 632-647. [CrossRef]

31. Promentilla, M.A.B.; Aviso, K.B.; Lucas, R.I.G.; Razon, L.F.; Tan, R.R. Teaching Analytic Hierarchy Process (AHP) in undergraduate chemical engineering courses. Educ. Chem. Eng. 2018, 23, 34-41. [CrossRef]

32. AHP Priority Calculator. 2018. Available online: https://bpmsg.com/academic/ahp_calc.php/ (accessed on 27 June 2018). 
33. Heywood, I.; Carver, S.; Cornelius, S. An Introduction to Geographical Information Systems, 3rd ed.; Pearson: London, UK, 2006; pp. 154-196. ISBN 0-13-129317-6 (pbk).

34. Siljander, M.; Venalainen, E.; Goerlandt, F.; Pellikka, P. GIS-based cost distance modelling to support strategic maritime search and rescue planning: A feasibility study. Appl. Geogr. 2015, 57, 54-70. [CrossRef]

35. Zhang, H.; Yao, Z.; Yang, Q.; Li, S.; Baartman, J.E.M.; Gai, L.; Yao, M.; Yang, X.; Ritsema, C.J.; Geissen, V. An integrated algorithm to evaluate flow direction and flow accumulation in flat regions of hydrologically corrected DEMs. Catena 2017, 151, 174-181. [CrossRef]

36. ArcMap. 2018. Available online: http://desktop.arcgis.com/en/arcmap/10.3/tools/cartography-toolbox/ how-simplify-line-works.htm/ (accessed on 5 March 2018).

37. Shi, W.; Cheung, C. Performance Evaluation of Line Simplification Algorithms for Vector Generalization. Cartogr. J. 2006, 43, 27-44. [CrossRef]

(C) 2019 by the authors. Licensee MDPI, Basel, Switzerland. This article is an open access article distributed under the terms and conditions of the Creative Commons Attribution (CC BY) license (http:/ / creativecommons.org/licenses/by/4.0/). 